\title{
MEDIA BUKU SEBAGAI REPRESENTASI IDEOLOGI PENULIS
}

\author{
Nova Darmanto', Nurul Akmalia², \\ 1,2 Program Studi Penerbitan, Jurusan Penerbitan, Politeknik Negeri Media Kreatif, Jakarta \\ Korespondensi: Jalan Srengseng Sawah, Jagakarsa, Jakarta Selatan \\ Surel: novadarmanto@polimedia.ac.id
}

\section{INFO ARTIKEL}

\section{Sejarah Artikel:}

Diterima: 02/01/2021

Direvisi: 15/01/2021

Dipublikasikan:30/01/2021

e-ISSN: 2721-0995

p-ISSN: 2721-9046

\section{Kata Kunci: \\ Buku \\ Ideologi Penulis \\ Penerbit \\ PenerbitanMedia \\ Representasi}

Keywords:

Books

The authors' ideologies,

Publisher

PublishingMedia

Representation

\begin{abstract}
ABSTRAK Media Buku sebagai Representasi Ideologi Penulis. Teks-teks yang dibuat oleh para penulis memberi pengaruh yang sangat luar biasa dalam peradaban manusia. Media buku dijadikan sebagai alat kontrol lembaga kekuasaan kerajaan dengan menciptakan aturan-aturan melalui wacana bahasa dalam media buku. Penelitian ini bertujuan untuk menganalisis media buku yang menjadi alat representasi bagi ideologi para penulisnya. Metode yang digunakan dalam penelitian ini adalah deskriptif kualitatif dengan menganalisis media melalui studi literatur dan pendekatan representasi sebagai dasar penelitian. Hasil dari penelitian ini menunjukkan bahwa sebuah bentuk tulisan dalam sebuah media seperti media buku merupakan bentuk reprensentasi dan membentuk identitas penulisnya. Tidak hanya itu, penerbit juga ikut andil dalam penentuan pesan-pesan dalam media buku. Penerbit yang menerbitkan media buku memiliki banyak kepentingan. Kepentingan penerbit media buku sangat beragam, antara lain kepentingan politik, kepentingan ekonomi dan kepentingan agama. Pada akhirnya, pertarungan antara kebijakan penerbit media buku dengan ideologi penulis diakhiri dengan keputusan untuk menerbitkan naskah tulisan sebagai simbol yang merefleksikan ideologi pengarang.
\end{abstract}

ABSTRACT Book as a Representation Medium of the Author's Ideology. The texts written by the authors have had a tremendous influence on human civilization. The book was used as a control tool for royal power institutions by creating rules through language discourse. This study intends to analyze the media of books to represent the authors' ideologies. The method used in this research is descriptive qualitative by conducting analyses through literature studies and representation approach. This study indicates that writing a book represents and forms its identity. The authors make writing in the form of messages on book by using language to explore knowledge and find information that is different from the ideological ideas. Each writer's ideology emphasizes his efforts to create a thought system through symbolic practices structured by messages in written text. It will then affect the provision of knowledge or information to readers. Not only that, but publishers also took part in determining messages in the book. Publishers have many interests. The interests are various, including political, economic, and religious interests. The contention between book publishers' policies and the ideology of writers ended with the emergence of the decision to publish a written text as a symbol that reflects the author's ideology. 


\section{PENDAHULUAN}

Pembahasan dalam tulisan ini berkaitan dengan keberlangsungan praktik representasi ideologi melalui media buku. Sebagai media, buku adalah "pemain lama". Media buku merupakan media pertama yang menjadi permulaan dari terciptanya serangkaian bentuk media massa yang ada hingga saat ini. Permulaan media buku tidak terletak pada masa percetakan buku oleh Gutenberg di Eropa, tetapi lebih lama lagi. Bermula dari digunakannya tanah liat, kulit binatang, kertas kain sebagai media dasar tulis dan digunakan papyrus di Mesir maupun kertas kain di China sebagai bahan dasar dalam membuat kertas. Pada masa abad pertengahan, sejarah media buku modern memang bermula di Eropa akan tetapi gagasan tentang buku sudah berlangsung sejak lama. Masyarakat Sumeria dan Mesir telah lama memperkenalkan banyak konvensi dalam membuat buku yang masih digunakan hingga saat ini. Dari buku yang berbentuk objek seni sampai terjadi perkembangan teknologi yang menjadikan buku lebih sederhana dan murah, kemudian menjadikan buku sebagai bagian dari media komunikasi (McLuhan, 1994; Scheder, 1976; Fidler, 2003; Danesi, 2010; Mc. Quail, 2011).

Fenomena praktik melalui representasi sesuatu yang bersifat umum dalam masyarakat dan sudah sangat lama terjadi. Dalam penerapannya, biasanya dilakukan pemahaman konteks dengan cara melakukan ekplorasi media atas wacana teksnya. Media tidak selalu menyajikan kepada kita sebuah cermin yang utuh, tetapi konten media merupakan susunan representasi dunia yang sudah diseleksi dan dikemas. Kenyataan ini didasari bahwa konten media tidak selalu mencerminkan peristiwa yang netral dan secara sempurna. Nyatanya, suatu media akan terlebih dahulu menyeleksi apa yang akan dimasukkan dalam kontennya (Ibrahim dan Akhmad, 2014). Hal ini didasarkan pada pengertian representasi sebagai bentuk gambaran mengenai suatu hal yang terdapat dalam kehidupan yang digambarkan melalui suatu medium. Seperti dinyatakan oleh Hall (1982) Representaion is a very different notion from reflection. It implies the active work of selecting and presenting, of structuring and shaping. Representasi merupakan suatu bentuk kehidupan sosial yang dicapai dengan melakukan lebih banyak penyelidikan terhadap bentuk-bentuk makna dalam teks yang ada dan muncul dalam masyarakat, serta bagaimana mereka dihasilkan dari makna yang ada dan ada dalam konteks yang berbeda yang terjadi dalam tatanan kehidupan sosial.

Buku sebagai media material teks telah lama memberikan kontribusi pada wacana informasional tentang berbagai wacana yang tersublimasi ke dalam simbol bahasa dalam tulisan atau naskah-naskah kitab suci, teks sastra, dan teks ilmiah. Sebagai medium, buku adalah objek material (Escarpit, 1966; Kleden, 1999; Fidler, 2003; Danesi, 2010). Buku yang telah ada selama lebih dari 4.000 tahun adalah media yang luar biasa bagi mereka yang dapat membaca, di mana pesan dapat dienkripsi dan direproduksi, digandakan, dipindahkan, diambil, dan diterjemahkan oleh siapa saja yang memiliki kemampuan menafsirkan dan siapa saja yang dapat membaca. Bahkan, buku telah menjadi pesan dan juga artefak karya seni dalam serangkaian perjalanan sejarah dalam dunia komunikasi. Diungkapkan McLuhan, medium buku telah menjadi pesan itu sendiri (McLuhan, 1994). 
Pengaruh media buku sangat luar biasa, sehingga dapat disebutkan bahwa representasi melalui buku menengarai adanya fakta-fakta bahwa isi media buku memberi dampak yang sangat besar. Seperti yang dinyatakan McLuhan (Littlejohn dan Foss, 2009), bahwa media buku terpisah dari apapun isi yang disampaikannya, baik dari adanya pengaruh individu maupun pengaruh masyarakat. Buku memengaruhi pembaca terlepas dari apa yang dibaca begitupun media lain. Namun, semenjak lama tidak ada perubahan atas media bernama buku. Sebagai material, buku merupakan tumpukan-tumpukan tanah liat, daun, kulit binatang, kain, kertas, digital yang terdiri dari kumpulan teks yang dibaca dan digunakan secara fungsional atas berbagai praktik-praktik kehidupan manusia melalui agama, pendidikan, teknologi ataupun berbagai keluaran atas pemikiran manusia hingga saat ini.

Representasi ada di lingkungan yang selalu berbeda dan ada dalam bentuk material yang berbeda serta berkembang sebagai respons terhadap perubahan yang terjadi. Setiap representasi dalam setiap konteks diproduksi, ditampilkan, digunakan, dan dipahami dalam konteks sosial tertentu di mana setiap representasi menghadirkan konteks yang tidak termasuk dalam teks melalui beragam bentuk media. Seperti yang dikatakan Danesi (2010), representasi adalah proses menangkap ide, informasi atau pesan secara fisik. Lebih tepatnya, ini dapat didefinisikan sebagai penggunaan "tanda" (gambar, suara, dan simbol lainnya) untuk mewakili atau mereproduksi sesuatu yang diserap, dirasakan, dan dibayangkan dalam bentuk fisik.

Permasalahan mengenai media buku sebagai sebuah wacana, tidak dapat dipisahkan dari relasi saling keterkaitan antara bahasa yang digunakan di dalamnya sebagai alat representasi, pengetahuan yang melandasinya, serta bentuk-bentuk kepentingan dan kekuasaan yang beroperasi di balik bahasa dan pengetahuan tersebut. Keberadaan media buku tidak dapat dipisahkan dari ideologi yang membentuknya, yang pada akhirnya memengaruhi bahasa yang digunakan, penciptaan serta pengetahuan yang dihasilkannya tanpa pengecualian terjadi di dalam operasional pembuatan media buku.

Salah satu fungsi media buku adalah menampilkan, menawarkan serta mendorong serangkaian wacana kepada masyarakat. Diskursus dapat disimpulkan dari teks-teks yang tersusun secara sistematis karena yang terbentuk mencerminkan praktik-praktik ideologis tertentu. Misalnya, dengan memahami ideologi dan konteks dari proses-proses di atas, sebuah naskah tulisan dapat dianalisis kecenderungan ideologisnya. Teks itu tidak netral tetapi memiliki keterwakilan atas bentuk-bentuk ideologis dan hal ini mewakili ideologi seseorang atau kelompok yang dapat diidentifikasi sebagai seorang kapitalis, pluralis, liberal, fundamentalis.

Bagi penulis, dari masa awal peradaban hingga modern, media buku menjadi alat yang sangat umum digunakan dalam menyusun teks-teks baik secara alfabetis maupun melalui teks teks visual. Seorang penulis dengan sendirinya telah menjadi seorang ideolog yang menanamkan ideologinya melalui serangkaian tulisan yang dibuatnya. Ideologi adalah pikiran yang terorganisasi, yakni nilai, orientasi, dan kecenderungan yang saling melengkapi 
sehingga membentuk perspektif-perspektif ide yang diungkapkan melalui komunikasi dengan media teknologi dan komunikasi antarpribadi (Sobur, 2004). Dengan demikian, ideologi apapun bisa diartikan sebagai ide atau gagasan.

Teks-teks yang dibuat oleh para penulis memberi pengaruh yang sangat luar biasa dalam peradaban manusia, terutama dalam memengaruhi berbagai pemikiran manusia. Kemunculan media buku merupakan salah satu ide dan peran dari penulis. Berbagai paradoks pengetahuan yang muncul ketika media menjadi bagian dari sebuah sistem ideologi. Keberadaan ideologi merembes ke berbagai jenis buku yang disebarkan sebagai pengetahuan, sudah tentu terbentuknya ideologi dalam media buku hadir melalui karakateristik dan patron pada budaya yang berbeda pula. Oleh sebab itu, media buku semenjak lama memang tidak berada di dalam ruang hampa. Berbagai wacana tertulis di dalam simbol-simbol teks pada media buku dan selalu memunculkan makna. Buku merupakan media yang terbatas jumlahnya di masa lampau. Oleh karena itu, media buku dijadikan sebagai alat kontrol lembaga kekuasaan kerajaan dengan menciptakan aturanaturan melalui wacana bahasa dalam media buku.

\section{TINJAUAN PUSTAKA}

\section{Media Buku}

Seperti yang diungkapkan oleh Escarpit (1966: 19), bahwa seperti apapun yang hidup, buku itu tidak untuk didefinisikan. Setidaknya, belum ada yang bisa memberikan definisi yang lengkap dan final tentangnya, karena buku bukanlah benda seperti benda lainnya, buku memiliki karakteristik sendiri. Berdasarkan ungkapan Escarpit, hal ini menunjukkan bahwa buku dapat didefinisikan sesuai dengan ruang lingkupnya. Buku dapat saja dianggap sebagai benda material, produksi budaya, alat komunikasi, media massa, yang satu sama lain terhubung pada setiap bagiannya. Sementara itu, istilah media dapat merujuk pada dua hal, pertama media sebagai bentuk material dan dimaksudkan hanya sebagai alat ataupun sarana yang pada gilirannya akan menggambarkan bahwa buku dianggap sebagai benda budaya dan yang kedua media dapat disebut sebagai alat komunikasi untuk memenuhi tuntutan massa di mana buku dituntut untuk dapat memenuhi kebutuhan terhadap bacaan dari khalayak.

Selama berabad-abad, inisiatif pengembangan buku bertumpu dan berfokus pada bentuk objek materialnya itu sendiri seperti berbentuk gulungan atau lembaran dengan bahan sepert tanah liat, daun, kulit binatang dan perkamen yakni jenis kertas dengan hasil penemuan yang lebih modern; atau dengan duplikasi. Media buku yang lebih modern merupakan keturunan langsung dari model ini yakni berbahan dasar papyrus dan penggunaannya pun serupa. Pada periode abad ke-19, pada masa ini buku mengalami pencapaian yang luar biasa dengan diterbitkan banyak buku dalam jumlah yang besar, di mana banyak bermunculan jaringan komunikasi dibangun seperti lembaga penerbitan serta toko buku bahkan perpustakaan untuk memenuhi kebutuhan masyarakat industri terhadap media buku. Menurut Briggs dan Burke (2006:67), adanya pasar untuk media buku 
mendorong naiknya jumlah para penulis dalam membuat naskah buku.

Buku mengalami perkembangan luar biasa, konsekuensi dari perkembangan ini membuat definisi buku menjadi sangat beragam apabila didefinisikan. Jika kita memilikinya, kita hanya memiliki kertas di tangan kita: buku itu ada di tempat lain. Tetapi juga ada di halaman-halamannya, dan pikiran sendiri tidak dapat membuat sebuah buku tanpa dukungan dari kata-kata yang tercetak. Buku adalah mesin baca, tetapi tidak pernah bisa digunakan secara mekanis. Sebuah buku yang dijual, dibeli atau ditangani tidak diperlakukan sebagai komoditas umum karena jumlahnya banyak dan unik dalam persediaan yang melimpah tetapi berharga.

Media buku menjadi satu-satunya yang telah menjelajah pada rentang waktu yang sangat panjang. Melalui berbagai bentuk media seperti tanah liat, daun, kulit binatang, kain, kertas, digital, dan berupa lembaran bergulung, diikat dan dijahit. Perjalanan sejarah panjang media buku mengalami pasang surutnya yang tak berarti mengalami perjalanan tanpa rintangan dalam melakukan berbagai representasi dan oleh sebab keingintahuan untuk memahami konteks-konteks yang ada di dalam setiap teks yang dikonstruksikan. Pengaruh buku dalam melakukan representasi sangat luar biasa. Maka dari itu, tidak ada media lain manapun yang memiliki kemampuan dalam melakukan representasi sehebat media buku, baik dilihat melalui penggunaan makna maupun tanda bahkan berdasarkan keragaman ideologi penulisnya.

Pada esainya yang tertuang dalam sebuah buku yang bertajuk Buku di Indonesia: Perspektif Ekonomi Tentang Kebudayaan (1999: 22) Ignas Kleden menjelaskan bahwa buku dapat dipandang dari segi budaya (cultural product), sebuah benda yang menjadi perwujudan fisik dari pikiran, perasaan, dan pengalaman manusia. Sebagai kebudayaan fisik, dan dalam kedudukan sebagai artefak, buku dapat dibandingkan dengan meja, kursi, mobil, sepatu atau benda-benda kebudayaan fisik lainnya. Di sisi lain, istilah media dapat merujuk pada lembaga, organisasi, atau korporasi media massa, misalnya nama sebuah stasiun berita, atau penyiaran radio atau secara umum disebut sebagai media massa. Sebagai produk budaya, media buku memiliki peran penting dalam representasi aspekaspek yang diwakilinya. Partisipasi merupakan proses penafsiran pesan oleh media massa, dan proses pada setiap pemaknaan pada setiap teks-teks bahasa ini tidak lepas dari apa yang disebut representasi.

aaaMeskipun tidak termasuk dalam ranah jurnalistik, hakikatnya buku merupakan bentuk media massa yang berkontribusi menyebarkan pengetahuan secara luar biasa. Menurut Baran (2019:122), buku merupakan "massa" dengan unit terkecil dari media massa yang ada, baik dilihat berdasarkan jangkauan khalayak pembaca maupun dalam skala industri itu sendiri. Fakta ini membentuk sifat hubungan unik antara media dan publiknya sehingga dapat disebutkan bahwa berdasarkan fungsinya, media buku melalui model komunikasi linear, berperan sebagai alat yang digunakan antarindividu untuk menyampaikan pesan suatu informasi oleh komunikator kepada komunikan sebagai penerima pesan. Pada kenyataannya, media buku telah mengawali upaya untuk melakukan langkah-langkah 
dalam melakukan representasi yang telah dilakukan pada bentuk teks-teks oleh penulis melalui media buku semenjak lama.

Jika ditelusuri secara seksama, melalui penggunaan simbol-simbol sebagai bahasa, media buku begitu dominan dalam menyebarkan pengetahuan. Semenjak lama, media buku melalui ideologi yang ada di dalam dirinya berupaya mewujudkan amanat peradaban. Kenyataan itu dapat diamati melalui sejarah serta berbagai karakteristik fitur-fitur buku yang tercipta. Jalaluddin Rakhmat (1984) mengemukakan empat karakteristik buku sebagai kekuatan budaya yakni buku menjembatani jarak sejarah, buku memberikan kedalaman, buku menyajikan informasi yang terpercaya, buku mudah dibaca dimana-mana (portabel).

Meskipun sebagai media material, media buku juga sarat dengan berbagai tanda berupa teks-teks yang memiliki makna sehingga media buku dianggap juga berisi berbagi informasi. Di sisi lain, dibantu dengan penggunaannya, huruf alfabet juga melengkapi media buku dengan munculnya berbagai jenis huruf dan memungkinkan informasi terekam, disimpan, dan ditransfer secara efektif dalam bentuk media buku-buku yang ditulis dengan tanah liat, papirus, dan perkamen. Melalui sistem abjad yang beragam memungkinkan media buku dapat melestarikan dan menarasikan berbagai peradaban budaya yang ada (Danesi, 2010: 71).

Menurut McQuail (2011, 27-30) sejarah media cetak bermula dari buku cetak. Kata media ditekankan oleh McQuail sebagai saluran komunikasi. Media adalah pengantar pesan dari pengirim ke penerima pesan. Dengan demikian, media merupakan wahana penyalur pesan. Media sebagai alat saluran komunikasi dapat membantu keperluan dan aktivitas yang membawa informasi dan pengetahuan melalui proses interaksi antara yang memberi pesan kepada penerima pesan. Secara harfiah istilah media dimaknai secara berbeda untuk menjelaskan dua pengertian, yakni digunakan untuk menunjuk kepada alat atau teknologi yang digunakan untuk komunikasi seperti kertas, gelombang radio, tulisan atau kata yang diucapkan. Namun, dalam konteks media buku, model komunikasi yang terjadi berifat linear. Komunikasi yang berlangsung linear merupakan model suatu penyampaian pesan dari seorang komunikator kepada komunikan, baik secara langsung maupun tidak langsung, yang memanfaatkan berbagai media komunikasi.

Menurut Baran (2019:67), budaya dan komunikasi tidak dapat dipisahkan. Lalu media massa dalam hal ini media buku merupakan bentuk komunikasi yang sangat kuat, menyebar, dan kompleks. Dengan penggunaan mesin cetak yang semakin meluas, maka banyak bermunculan bentuk-bentuk media yang menggunakan kertas serta penanda perkembangan media buku yang sebelumnya hanya di tulis tangan. Seperti yang dikatakan oleh Escarpit, sebuah buku dianggap sebagai sekadar sebuah benda material yang dihasilkan dalam kemajuan industri (Escarpit, 2008: xi). Kenyataan yang menarik dari teknologi cetak adalah membawa perubahan atas kecepatan serta jumlah oplah yang dihasilkan lebih banyak dan produk yang dihasilkan atas transformasi hasil penemuan mesin cetak tersebut berbentuk buku (Fidler, 2003:66). Melalui buku ilmu pengetahuan melakukan ekspansi melalu ide-ide segar dan baru. Secara pasti, keberadaan buku tidak dimulai kemarin 
(Danesi, 2010:10). Sejarah buku telah membentang panjang dalam mengubah berbagai hal kehidupan manusia.

Buku diakui sebagai yang terpenting terbentuk disiplin baru dalam perkembangan ilmu pengetahuan. Bahkan, berdasarkan fungsinya, dapat masuk sebagai kategori utama dalam perkembangan sejarah sosial dan budaya dari komunikasi cetak karena lahirnya buku sebagai cara untuk memahami bagaimana ide-ide disebarkan melalui media cetak dan bagaimana eksposur pada kata-kata tercetak memengaruhi pemikiran dan perilaku umat manusia.

\section{Perihal Representasi}

Media dianggap memiliki kekuatan sebagai pembentuk di mana terdapat keyakinan pada setiap konten yang disebarkan oleh media yang memiliki kekuatan untuk memengaruhi masyarakat (Ibrahim dan Akhmad, 2014:3). Berdasarkan sudut pandang ini, setiap penggambaran yang terdapat di media memberikan kemungkinan besar pengaruh kepada audiens. Media sebagai pembentuk telah memberikan tekanan terhadap media yang dianggapnya memilki kekuatan memengaruhi dengan menggunakan kekuatan konten medianya. Di saat yang bersamaan media telah melakukan aktivitas representasinya guna memengaruhi audiens sebagai penerima pesan. Menurut Stuart Hall, representasi adalah kemampuan untuk mendeskripsikan atau berimajinasi dimana representasi dianggap sebagai produksi makna yang berasal dari suatu konsep melalui bahasa yang merujuk kepada objek mengenai orang atau peristiwa, baik secara nyata maupun imajiner (2005: 18-20).

Sementara itu, Danesi (2012) dalam uraiannya menjelaskan bahwa representasi dapat di mengerti dan dipahami melalui penggunaan tanda seperti teks, gambar, suara dan sebagainya. Setiap bentuk tanda baik dalam bentuk verbal dan nonverbal untuk menghubungkan, mendeskripsikan, memotret atau menghasilkan sesuatu yang dilihat, dibaui, dibayangkan atau dirasakan melalui serangkaian proses perekaman gagasan, pengetahuan, atau pesan secara fisik, baik bermakna denotatif maupun konotatif. Stuart Hall (1997:15) mengingatkan bahwa representasi berarti menggunakan bahasa untuk mengatakan sesuatu yang bermakna atau untuk menggambarkan dunia yang bermakna kepada orang lain. Setiap makna akan dikonstruksi oleh sistem representasi dan maknanya akan dihasilkan oleh sistem bahasa yang fenomenanya muncul tidak hanya melalui ekspresi verbal tetapi juga secara visual. Makna pada budaya selalu terhubung dan dipahami melalui bahasa yang akan dibagikan dengan setiap anggota budaya. Hall sudah tentu melihat realitas setiap makna sebagai sifat yang melekat pada teks dalam bahasa sehingga menurut Hall setiap representasi dapat dijadikan sebagai sarana komunikasi dan interaksi sosial. Bahkan menekankan kebutuhan terhadap representasi menjadi kebutuhan dasar komunikasi dimana tanpa representasi maka manusia tak mungkin dapat berinteraksi.

Fakta lain dalam representasi bahwa operasional dari representasi dilakukan melalui tahapan proses sehingga membentuk menjadi apa yang disebut sebagai sistem representasi. Sistem ini bukan merupakan ide atau konsep individu, melainkan sebagai sebuah sistem 
ataupun metode dalam mengorganisasi, menginternalisasi, dan mengklasifikasi konsep dari berbagai kompleksitas relasional. Melalui visinya, Stuart Hall (1997:15) memperlihatkan representasi melalui konsep-konsep abstrak yang ada di benak kepala dan diterjemahkan ke dalam bahasa sebagai bentuk penghubung konsep atau gagasan yang ada di benak kita sehingga bisa diekspresikan dengan sebuah tanda tertentu seperti simbol sebagai perantaranya.

Menurut Hall (1997:15), sebagai sebuah sistem maka proses bekerja representasi dilakukan melalui dua proses yang meliputi tahap pertama, yakni tahap konseptualisasi (representasi mental) di mana dalam melakukan representasi maka segala bentuk realitas ataupun fakta imajiner diharuskan menjadi konsep dalam kognitif manusia (peta konseptual). Representasi mental ini pada akhirnya membentuk segala yang abstrak di benak kepala seseorang. Selanjutnya, pada tahap kedua merupakan tahap menjelmakan konsep dalam bahasa (representasi bahasa), yakni konsep pertama yang telah terbangun dalam pikiran didistribusikan dan ditransaksikan dengan manusia lainnya melalui bahasa. Bahasa yang digunakan tidak terbatas pada bahasa verbal tetapi juga meliputi bahasa nonverbal. Hall (1997:15) juga telah memetakan beberapa pendekatan dalam memahami representasi. Pertama, pendekatan reflektif, yakni bahasa bekerja seperti cermin yang mencerminkan arti sebenarnya dari segala sesuatu di dunia. Kedua, pendekatan intensional, yakni reperesentasi dengan menggunakan bahasa untuk memandang sesuatu. Pendekatan kedua terhadap makna dalam representasi berbeda dengan pendekatan reflektif dan terjadi sebaliknya. Pendekatan ini mengatakan bahwa seseorang pembicara, penulis, atau siapa pun yang mengungkapkan makna uniknya kepada dunia melalui bahasa. Ketiga, pendekatan konstruktif, yakni menciptakan makna melalui bahasa yang digunakan.

\section{Ideologi Penulis}

Ideologi adalah ide atau gagasan yang memberikan gambaran dunia yang terorganisasi, tentang tempat dan hubungan seseorang dengan orang lain, dan tentang cara berpikir seseorang dan sangat penting membentuk dan juga bagi pengalaman manusia. Ideologi adalah sesuatu yang sering dijadikan sebagai paham atau identitas kesadaran individu manusia baik disadari maupun tidak disadari. Dalam arti yang paling luas, seperti diungkapkan oleh Sobur (2004: 64) bahwa ideologi adalah pikiran yang terorganisasi yang melengkapi dirinya sendiri untuk menciptakan perspektif tentang ide-ide yang diungkapkan melalui media teknologi dan komunikasi antarpribadi melalui nilai, orientasi, dan kecenderungan yang saling melengkapi. Sementara itu, menurut Raymon (Fiske, 1990) mengemukakan tiga konsep berkaitan dengan ideology. Pertama, ideologi sebagai sebuah sistem kepercayaan. Kedua, ideologi sebagai sebuah sistem keyakinan. Ketiga, ideologi sebagai penggambaran dalam proses memproduksi makna. Ketiga pemetaan konsep tersebut saling berkaitan satu dengan lainnya (Rusadi, 2015:54).

Menurut Thompson (1984:17), penggunaan istilah ideologi memiliki sejarah yang panjang dan kompleks yang terbukti dalam karya banyak penulis dan telah meresap ke dalam berbagai disiplin ilmu sosial dan humaniora modern. Menurutnya, istilah ideologi 
digunakan dalam dua cara yang berbeda dalam penelitian yang mendalam. Di satu sisi, ideologi digunakan oleh beberapa penulis sebagai istilah deskriptif murni; sebagai sistem pemikiran, sistem kepercayaan, praktik simbolik tindakan sosial dan politik. Penggunaan istilah ini telah menghasilkan apa yang disebut pemahaman netral.

Berdasarkan pemikiran Thompson tersebut, seorang penulis menjadikan pesan sebagai instrumen yang melibatkan bahasa yang ditulis oleh penulis pada saat mengeksplorasi berbagai pengetahuan dalam menggagas berbagai ideologi yang ada dalam pikirannya. Secara positif, setiap ideologi penulis lebih menekankan pada upaya membangun sistem pemikiran melalui praktik simbolik yang tersusun melalui pesan berupa naskah tulisan dan kemudian akan dapat memberikan efek berupa pengetahuan ataupun makna kepada pembaca pesan. Di lain pihak, praktik-praktik dalam ideologi penulis dapat saja berupaya memperlihatkan segenap pandangan melalui makna-makna yang terkandung pada penggunaan simbol berkaitan terhadap ideologi penulisnya dan bertujuan untuk membangun kesamaan pandangannya dengan pembaca pesan.

Melalui sisi yang lain, Liang Gie (1992:17) mendefinisikan menulis sebagai rangkaian kegiatan di mana seseorang dapat mengumpulkan ide dan menuangkannya ke dalam tulisan untuk memahaminya. Berdasarkan pandangan tersebut dapat disimpulkan bahwa menulis adalah kegiatan menyampaikan ide atau gagasan dalam suatu bahasa melalui bahasa tertulis yang dapat dipahami dan dipahami oleh pembaca. Pemisahan nama karya dan teks melibatkan cara pandang masyarakat terhadap pentingnya pengarang. Dalam berkarya, penulis berperilaku seperti ibu yang melahirkan. Peran penulis ini berkurang saat "isi" karya sudah tertuang ke dalam media buku dan karya isi setiap penulis tersebut adalah teks.

Dengan pengertian ini, ide ataupun gagasan merupakan ideologi. Setiap penulis akan menggunakan berbagai gagasaan ataupun idenya ke dalam sebuah tulisan. Sudah tentu penulis dianggap sebagai orang yang menampilkan tulisan yang dituangkan ke dalam media. Ideologi penulis mewakili dirinya sendiri dimana ideologi dibentuk atas berbagai pemahaman atas ideologi-ideologi yang tersublimasi melalui pencerapan dan membentuk ideologi penulisnya. Bagi para penulis, penggunaan media buku tidak diragukan lagi perannya sebagai sumber informasi utama bagi masyarakat ilmiah. Di antara semua media, buku dianggap orang sebagai sumber informasi yang relatif terhormat dan terpercaya. Media buku dibaca oleh orang yang betul-betul memerlukannya. Buku cenderung dicerna lebih baik. Dibandingkan dengan media lain, buku memiliki fungsi "retrieval" yang memungkinkan pengujian dan pengecekan berkali-kali. Akibat lebih lanjutnya ialah buku lebih mampu menanamkan pengertian. Dalam hal ini, sebagai media pendidikan, buku tidak dapat ditandingi oleh media yang lain.

\section{METODE}

Metode yang dipakai dalam penelitan ini adalah melalui pendekatan kualitatif. Pendekatan kualitatif merupakan suatu proses penelitian dan pemahaman yang berdasarkan 
pada metodologi yang menyelidiki suatu fenomena sosial dan masalah manusia. Pada pendekatan ini, penulis membuat suatu gambaran kompleks, meneliti kata-kata, dan melakukan studi pada situasi yang alami (Creswell, 1998:15). Pendekatan kualitatif biasanya digunakan untuk dapat mengetahui makna yang tersembunyi dari sebuah fenomena sosial, memahami interaksi sosial, untuk mengembangkan teori dan juga digunakan untuk memastikan keabsahan data.

Berdasarkan pemilihan objek, penulis bermaksud berupaya menganalisis mengenai media buku yang menjadi alat representasi bagi ideologi para penulisnya sehingga orientasi penelitian ini selanjutnya akan berupaya menggambarkan makna maupun pengetahuan dalam penelitiannya. Dalam hal ini penelitian yang dilakukan menggunakan metode penelitian deskriptif kualitatif dengan menganalisis media melalui studi literatur dan pendekatan representasi sebagai dasar penelitian. Berkaitan dengan keduanya, dan dengan melalui berbagai pertimbangan bahwa analisis media dapat melihat lebih jelas bagaimana seorang penulis menggunakan buku dalam membangun ideologinya.

\section{HASIL DAN PEMBAHASAN}

Dalam pembahasan ini, ada sedikit penyebutan tentang larangan surat kabar dan buku. Sejarah kelam buku-buku tersebut berlanjut selama ratusan tahun, tepatnya peristiwaperistiwa penghancuran buku tersebut oleh penakluk Mongol Genghis Khan dan Hülagu Khan di abad ke-12. Puluhan ribu buku dibakar dan dibuang di Sungai Trigis. Di beberapa negara, pelarangan buku acapkali terjadi baik pada fiksi maupun nonfiksi. Umumnya pelarangan buku bersifat ideologis. Bahkan pelarangan tidak terbatas pada buku, di Turki Ottoman, sempat terjadi pelarangan mendirikan percetakan dan didapati adanya hukuman mati bagi siapa saja yang mendirikan percetakan (Briggs dan Burke, 2006). Di Indonesia, sejak mengawali kemerdekaan sudah lebih dari 300 buku yang telah dilarang. Salah satunya adalah buku karya penulis Pramoedya Ananta Toer yang berjudul Hoa Kiau di Indonesia. Pelarangan buku juga terjadi pada karya buku seperti Mereka yang Dilumpuhkan, Subuh, Di Tepi Kali Bekasi, Bukan Pasar Malam, Tjerita Dari Blora, Dalih Pembunuhan Massal: Gerakan 30 September dan Kudeta Soeharto, Suara Gereja bagi Umat Tertindas: Penderitaan Tetesan Darah dan Cucuran Air Mata Umat Tuhan di Papua Barat, Keluarga Gerilya, Perburuan, Lekra Tak Membakar Buku: Suara Senyap Lembar Kebudayaan Harian Rakyat 1950-1965 Enam Jalan Menuju Tuhan, hingga, Mengungkap Misteri Keberagaman Agama, sebagai contoh buku yang pernah dilarang di Indonesia. Bahkan Pada 2012, Gramedia, toko buku terbesar di Indonesia, membakar ratusan eksemplar buku 5 Kota Paling Berpengaruh di Dunia karya Douglas Wilson. Di Indonesia, beberapa buku yang bermazhab kiri dilarang keberadaannya.

Pelarangan buku tersebut mencerminkan banyak terbitan buku yang berupaya mengukuhkan ideologi bagi penulisnya. Melalui keterampilan bahasa berupa tulisan, banyak media buku menyajikan naskah-naskah yang sarat dengan karakteristik ideologi yang dibangun oleh seorang penulis. Seorang penulis bukanlah sebuah wilayah hampa. Selain itu pula, merujuk kepada penulisnya, sebuah buku yang diterbitkan tidaklah berada 
di ruang hampa sehingga penerbitnya pun dalam menerbitkan sebuah tulisan dari seorang penulis juga tidak berada pula dalam ruang hampa. Pemikiran seorang penulis dipengaruhi secara langsung oleh banyak pengetahuan serta elemen-elemen sosial yang membentuk watak pemikiran penulis hingga menjadi pola ideologinya. Pemikiran seorang penulis yang diungkapkan dalam suatu teks atau bacaan melalui bahasa memiliki kecenderungan berupaya untuk menuliskan berbagai pendapatnya dalam tulisan faktual pengetahuan atau pengalaman yang tersimpan dalam benaknya dan dibangun demi menguatkan gagasan utama dalam tulisannya. Di dalam pemikiran yang paling objektif pun, unsur-unsur subjektivitas dalam gagasannya akan melekat dan terlibat secara aktual untuk membangun konsep objekivitas pemikiran dari seorang penulis.

Tidak mudah untuk mengungkapkan ide melalui tulisan, karena menulis bukan sekedar mendeskripsikan apa yang diucapkan atau membahas bahasa lisan secara tertulis. Menulis adalah kemampuan menggunakan pola bahasa tertulis untuk mengungkapkan suatu gagasan atau pesan. Artinya, gagasan penulis disampaikan dengan menggunakan simbol bahasa dalam pola yang memungkinkan pembaca memahami apa yang dikomunikasikan penulis. Seseorang dapat dikatakan mahir menulis jika yang dimaksud penulis sama dengan yang dimaksud pembacanya. Setiap ide adalah produk pemikiran, jadi meskipun seorang penulis tidak bisa lepas dari imajinasinya, menulis bukanlah hasil angan-angan. Imajinasi di sini adalah imajinasi yang terbentuk di dalam pikiran, dicerna oleh otak dan ditransmisikan dalam bentuk tulisan. Sebuah tulisan sudah tentu harus sesuai dengan pemikiran dan dirancang dengan aturan yang berlaku maka tulisan seorang penulis tidak terbatas pada angan-angan saja tetapi juga berasal dari realitas yang terjadi.

Gagasan penulis dapat diperoleh melalui wawasan dan pengetahuan yang luas. Dengan membaca, hal-hal baru diperoleh dan munculnya ide baru pun sangat memungkinkan. Setiap catatan bacaannya menjadi pengetahuan dan referensi dalam menemukan gagasan baru yang akan ditulis. Selain itu pengalaman dan kehidupan pribadi seorang penulis memberikan pengaruh terhadap setiap tulisan yang diterbitkannya. Sebuah tulisan merupakan gagasan yang didapat oleh sebab pengetahuan dan pengalamaan dari seorang penulis yang dibuat ke dalam tulisan dengan bahasa tertentu. Pada saat menulis, seorang penulis akan menanamkan buat pemikirannya ke dalam teks-teks yang disusun sedemikian rupa hingga menjadi wacana teks tertentu. Secara bersamaan, pada saat seorang penulis akan menulis gagasannya maka serta merta seorang menulis berupaya menanamkan berbagai ideologi melalui tulisannya.

Penyebaran ide-ide penulis secara alamiah terjadi melalui proses komunikasi, semakin banyak orang membaca teks buku, semakin baik pula ide-ide atau gagasan penulis. Cara mengomunikasikan atau membacakan ide ini kepada banyak orang adalah dengan menjualnya atau menugaskan penerbit untuk menerbitkan artikelnya. Sebuah tulisan merupakan abstraksi atas pemikiran yang didasari dari pengetahuan ataupun pengalaman seorang penulis yang dibuat secara subjektif berdasarkan bahasa. Seorang penulis menjadi sebab atas alasan utama terciptanya suatu tulisan. Dengan maksud yang sama, dalam 
memahami kehidupan seorang penulis maka dapat memberikan kontribusi dalam upaya memahami ideologi penulis.

Karya seorang penulis merupakan sebuah wacana teks. Dalam media buku, setiap naskah merupakan sebuah bentuk tulisan yang merupakan karya bagi penulisnya. Melalui karya tulisnya seorang penulis memiliki kedudukan yang penting dalam lembaga media. Hal itu dikarenakan, kedudukan teks bersifat otonom. Posisi seorang penulis akan dianggap penting karena makna yang terkandung dalam teks hanya dapat dipahami oleh penulisnya. Hal itu disebabkan sebuah tulisan atau teks bukan sekadar seperangkat kata yang tersusun, melainkan pada kenyataannya terdapat berbagai pengertian yang tertanam dalam teks yang memiliki konteks. Pada setiap konteksnya, diperlukan interpretasi di dalam wacana teks yang ditulisnya.

Jadi dapat dikatakan bahwa seorang penulis merupakan pengguna bahasa dan dapat dengan terampil menciptakan tulisan. Pengarang atau penulis adalah pencipta dan penyusun setiap gagasan yang kemudian disebarluaskan melalui media buku. Setiap gagasan penulis masih dinyatakan sebagai korpus mistik selama gagasan tersebut belum tertuang ke dalam bentuk tulisan. Sebuah gagasan yang berasal dari penulis akan dianggap sebagai korpus mekanikum apabila gagasan telah diwujudkan menjadi wacana atau serangkaian teks-teks. Perwujudan gagasan dapat diwujudkan melalui penggunakan bahasa.

Akibat dari harapan dalam mewujudkan gagasan tersebut, maka bagi seorang penulis, media buku merupakan saluran pesan dalam mewujudkan gagasan bagi seorang penulis. Sebuah tulisan dari seorang penulis, di dalam sebuah media telah berbentuk menjadi pesan sedangkan media buku menjadi saluran yang selama dipahami oleh penulis sebagai tempat dimana pesan dapat disampaikan kepada audiens. Media ini diperbanyak dan disebarkan untuk dibaca atau diceritakan kembali oleh pembaca kepada orang lain. Pesan adalah sekumpulan wacana teks yang dibangun berdasarkan kepentingan penulis. Pesan dari sebuah buku merupakan tulisan bagi seorang penulis. Kepentingan bagi seorang penulis adalah membuat tulisannya dapat dijadikan sebagai konten media buku. Hal itu merupakan upaya penulis untuk menanamkan ideologi yang dipahami untuk dapat diketahui oleh orang banyak. Seperti dikatakan oleh Becker (Littlejohn 1996: 236) bahwa setiap bahasa adalah setiap simbol yang menemukan ideologi, sehingga pilihan sekumpulan simbol, disadari atau tidak, adalah pilihan ideologi.

Sebuah naskah dalam media buku akan menjadi bentuk pesan dalam prosesproses komunikasi dan pesan dalam komunikasi memiliki arti yang sangat penting untuk membangun pengertian antara pembawa pesan dengan penerima pesan. Pesan bagi seorang penulis adalah naskah tulis yang disusun sedemikian rupa yang berasal dari ideologi penulis dan dibentuk melalui oleh pengetahuan ataupun pengalaman seorang penulis. Naskah dalam media buku merupakan konten berupa kumpulan ide ataupun gagasan penulis. Media buku sebagai media massa, sudah tentu tak terlepas dengan keadaan di mana pesan-pesan melalui bahasa yang tertuang di dalam naskah buku merupakan upaya dalam merepresentasi ideologi penulis. Dengan perkataan lain, setiap naskah yang terdapat 
dalam media buku merupakan bentuk dari praktik simbolik.

Ideologi yang ditanamkan seorang penulis dalam bentuk ideologi yang bersifat deskriptif murni; hanya sebagai sistem pemikiran, sistem kepercayaan, praktik simbolik tindakan sosial dan politik. Seorang penulis menjadikan tulisan dalam bentuk pesan pada media buku dengan menggunakan bahasa untuk mengeksplorasi pengetahuan dan menemukan informasi yang berbeda dengan gagasan ideologi yang ada dalam pikirannya. Sisi positifnya, ideologi masing-masing penulis menekankan pada upayanya menciptakan sistem pemikiran melalui praktik simbolik yang terstruktur oleh pesan-pesan dalam bentuk teks tertulis dan kemudian akan dapat memberi efek berupa bentuk pengetahuan atau informasi kepada pembaca melalui setiap tulisan yang telah menjadi pesan dalam sebuah media buku. Itulah cara-cara representasi yang telah terjadi.

Pesan dalam sebuah media buku berisikan berbagai bentuk tulisan dari penulisnya. Sebagai media komunikasi, buku hanya memberikan ruang pada pesan, karya tulisan seorang penulis dalam media buku akan berubah sebagai pesan. Oleh karena itu, pesan yang terdapat dalam media buku terbut yang tidak lain adalah tulisan dari seorang penulis. Tulisan menjadi sangat penting dalam kedudukannya sebagai pesan karena sebuah tulisan merupakan sebuah lambang/simbol untuk mengekspresikannya pikiran dan perasaan, pendapat, fakta, dan pengetahuan serta pengalaman yang konkret dan abstrak. Melalui pesan dalam bentuk tulisan pada media buku diharapkan menghasilkan dan menimbulkan efek tertentu.

Sebuah tulisan dalam media buku merupakan bentuk reprensentasi dan membentuk identitas penulisnya. Seseorang penulis dapat memperoleh suatu identitas ketika keberadaannya diinterpretasikan oleh orang lain dan media buku akan ditafsirkan oleh para pembaca tulisannya. Identitas yang dibangun oleh penulis merupakan upaya mengonstruksikan ideologi yang ada di dalam benak penulis. Di dalam media buku, bahasa menjadi unsur dominan yang digunakan sebagai bagian dari saluran komunikasi. Fungsi bahasa sebagai media komunikasi menjadikan bahasa memiliki pengaruh penting dalam kehidupan manusia. Selain itu, bahasa merupakan media yang paling efektif untuk menyampaikan ide, pemikiran, maksud, dan tujuan kepada orang lain. Bahasa tidak hanya sebagai alat komunikasi, tetapi juga sebagai saluran untuk merumuskan niat, ide, gagasan, menciptakan emosi, dan cara untuk berkolaborasi.

Dalam konteks ini, bahasa (Sobur, 2001: 88) tidak hanya sebagai alat untuk merepresentasikan realitas, tetapi juga menentukan bahasa relaksasi seperti apa yang akan terjadi atas realitas tersebut. Sobur berpendapat bahwa media buku memiliki peluang yang sangat besar untuk memengaruhi makna dan citra yang mengalir dari realitas yang mereka ciptakan. Hal ini menjelaskan bahwa kegiatan menulis dengan menggunakan bahasa sebagai bahan baku untuk menghasilkan informasi dan pengetahuan. Namun bagi media, bahasa bukan sekadar alat komunikasi untuk menyampaikan fakta, informasi, atau opini. Bahasa tidak hanya sebagai alat komunikasi untuk menggambarkan realitas, tetapi juga menentukan citra tertentu yang ditempatkan di hadapan pembaca. 
Media buku tidak diterbitkan dalam ruang hampa. Dalam hubungannya, penerbitan sebagai institusi media dipengaruhi secara langsung oleh banyak elemen sosial, ekonomi dan politik, dan oleh kondisi dan tren nasional dan internasional termasuk di dalam penulis juga memberikan dampak yang penting untuk diperhatikan. Media buku yang menjadi asal mula tulisan mengukuhkan ideologi penulisnya. Fakta ini tidak menjelaskan bahwa media buku berperan langsung dalam memperkuat suatu ideologi. Selama proses penulisan artikel yang berasal dari seorang penulis, kelahiran berlangsung dalam proses yang kompleks. Sebagai alat konstruksi, media buku merupakan sarana strategis bagi penerbit untuk menciptakan bahasa tulis melalui teks yang dihasilkan oleh seorang pengarang. Sebuah tulisan jelas merupakan bidang ideologis bagi pengarangnya dan ada bidang minat yang tersirat oleh simbol bahasa yang disatukan di dalamnya oleh seorang pengarang. Di sisi lain, penerbit yang menerbitkan media buku memiliki banyak kepentingan. Kepentingan penerbit media buku sangat beragam, antara lain kepentingan politik, kepentingan ekonomi, dan kepentingan agama. Bahkan, lingkungan penerbit buku bisa menjadi alat hegemonik untuk mempertahankan dominasi dan kekuasaan kelas penguasa.

Setiap penerbit akan melakukan seleksi terhadap naskah tulisan yang akan diterbitkan sebagai produk penerbit. Proses seleksi bukan hanya proses sekadarnya. Namun, ini adalah proses yang kompleks dan panjang yang melibatkan berbagai pertimbangan editorial yang ada. Beberapa evaluasi dilakukan untuk membuat keputusan yang tepat atas naskah tulisan yang dikirimkan oleh seorang penulis. Di ruang editorial, proses pemilihan naskah yang ditulis agar dapat diproduksi yang berasal dari naskah mentah hingga siap dicetak, merupakan proses pertarungan ideologis, setidaknya pertarungan terjadi antara penerbit dan penulis untuk mempertahankan ideologinya masing-masing. Pertarungan antara kebijakan penerbit media buku dengan ideologi penulis diakhiri dengan kemunculan keputusan untuk menerbitkan naskah tulisan sebagai simbol yang merefleksikan ideologi pengarang menjadi sebuah buku. Ruang editorial di penerbit adalah ruang sosial yang terdiri dari serangkaian struktur dan hubungannya. Struktur editorial dapat berupa kebijakan terstruktur baik secara tertulis maupun tidak, bersifat adat istiadat, yang memilki kewenangan dalam memilih naskah tulisan yang berasal dari para penulis. Dalam ruang editorial, setiap orang di dalamnya memiliki wewenang dan tanggung jawab yang berbeda. Berdasarkan kewenangan tersebut, dalam ruang editorial sering menjadi ruang pergulatan bagi para editor manajer produksi, manajer pemasaran, pemilik penerbitan.

Realitas media buku (teks informatif) merupakan hasil representasi pengkonstruksian. Tulisan di dalam media buku bukanlah produk orisinal, melainkan berasal dari seorang penulis dengan media sebagai alat konstruksi. Ini pertanda bahwa realitas media mencerminkan realitas penulis, bukan realitas sosial yang nyata. Dengan kata lain, kenyataan sebenarnya adalah realitas media buku (teks informatif) mencerminkan subjektivitas media dan penulisnya, karena realitas media buku sebenarnya diproduksi oleh seorang penulis yang pada kenyataannya ideologi dalam tulisan tidak dapat dipisahkan darinya subjektivitas penulis yang memiliki otoritas pengetahuan dan juga memahami cara-cara makna dapat 
tersampaikan ke dalam unit bahasa. Oleh karena itu, bahasa adalah alat utama media buku untuk merekonstruksi tanda-tanda tulisan seorang penulis. Pada saat melakukan pengkonstruksian tanda, bagian editorial dalam penerbit akan melakukan penyuntingan untuk mendeskripsikan ideologi penulis sesuai dengan keinginan media atau menarik minat pembaca. Ini menunjukkan bagaimana unit bahasa digunakan untuk menjeleskan realitas sebagai alat manipulasi.

Pada sisi lain, representasi merupakan proses reproduksi yang berkaitan dengan identitas di mana representasi diri adalah perilaku manusia yang berusaha menyampaikan informasi tentang diri sendiri kepada orang lain. Identitas adalah bagian penting dari konsep diri. Konsep diri bukan hanya gambaran deskriptif, itu juga penilaian diri penulis. Konsep diri memengaruhi cara orang memandang realitas dan juga mengacu pada persepsi yang dimiliki seseorang tentang dirinya sendiri.

Seperti diungkapkan oleh Liliweri (2015: 148-149) semua pikiran dan emosi individu yang merujuk pada orang sebagai objek, merupakan konsep diri. Identitas adalah bagian dari diri kita yang diketahui orang lain. Interaksi adalah cara penting untuk menemukan identitas. Media buku merupakan media yang berfungsi sebagai media interaksi yang bisa menyampaikan pesan apapun yang diinginkan seorang penulis. Dalam proses ini, penulis merepresentasikan dirinya untuk menciptakan identitas yang diinginkan penulis melalui tulisannya. Media buku di sini diartikan sebagai sarana untuk menciptakan identitas dan juga sebagai hasil penyebaran pesan oleh penulis.

Identitas penulis dapat dikemukakan melalui kemampuan dalam menuliskan karyanya. Seorang penulis adalah subjek bagi tulisannya. Sebagai orang yang menghasikan produk tulisan, maka karya-karya yang dihasilkan dianggap memiliki arti yang sangat penting. Hal itu disebabkan oleh hasil pemikiran penulis melalui teks-teks wacana yang dibangun dapat membangun wawasan pemikiran bagi para pembacanya.

\section{SIMPULAN}

Teks-teks yang ditulis oleh para penulis memiliki dampak yang luar biasa bagi peradaban manusia, terutama dengan memengaruhi berbagai pemikiran manusia. Maraknya media buku merupakan salah satu gagasan dan peran penulis. Perkembangan lain adalah peran penulis profesional sejak akhir abad ke-16, yang umumnya didukung oleh pembaca yang kaya. Setiap perkembangan ini telah menyebabkan munculnya pasar dan transformasi buku media menjadi komoditas. Representasi adalah cara sebuah penerbit untuk mendapat tulisan dari seorang penulis, karena media buku dalam pandangan penulis sebagai media yang dapat memproduksi tulisan. Di lain pihak seorang penulis juga melakukan upaya representasi. Hal ini disebabkan adanya anggapan penulis bahwa media buku adalah alat legitimasi bagi seorang penulis untuk dapat mentransformasikan gagasan/ideologinya ke dalam sebuah buku.

Selain itu, pembahasan medium buku dalam konteks kepentingan yang melandasinya ternyata tidak lepas dari berbagai paradoks ilmu yang juga dihasilkannya. Perbedaan 
paradoks pengetahuan yang muncul ketika media menjadi bagian dari sistem ideologis. Keberadaan ideologi merembes ke berbagai jenis kitab yang disebarluaskan sebagai ilmu pengetahuan, tentunya pembentukan ideologi dalam media buku ini melalui ciri dan corak dalam budaya yang berbeda. Oleh karena itu, media buku sudah lama tidak berada dalam ruang hampa. Media buku ditulis dalam simbol teks dan selalu menyampaikan makna. Namun, karena tulisan dibangun melalui rangkaian susunan teks yang rumit dan sulit. Maka ideologi seorang penulis dapat diketahui apabila seorang pembaca secara tuntas memahami tulisannya.

Pemikiran seorang penulis yang diungkapkan dalam suatu teks atau bacaan melalui bahasa memiliki kecenderungan berupaya untuk menuliskan berbagai pendapatnya dalam tulisan fakta pengetahuan atau pengalaman yang yang tersimpan dalam benaknya dan dibangun demi menguatkan gagasan utama dalam tulisannya. Di dalam setiap pengetahuan dan pengalaman tersebut, maka sebuah ideologi dapat dilahirkan dan membentuk menjadi ideologi bagi penulisnya. Media buku merupakan saluran bagi seorang penulis untuk dapat menyampaikan berbagai gagasan-gagasan pengetahuan yang didapatkan dan diharapkan dapat ditransformasikan ke dalam sebuah tulisan pada sebuah buku.

Penerbit dan penulis merupakan dua lembaga yang secara bersama-sama memiliki kesamaaan pandang sehingga sebuah tulisan dari seorang penulis harus dapat memiliki kesamaan visi dengan kebijakan penerbit. Penerbit merupakan lembaga media yang melahirkan buku. Selain profit, penerbit juga memiliki ideologi yang terangkum dalam kebijakan penerbit (publishing policy).

\section{DAFTAR RUJUKAN}

Alo Liliweri. (2015). Komunikasi Antar Personal. Jakarta: Kencana Prenadamedia Group.

Baran, Stanley J. (2019). Introduction to Mass Communication: Media Literacy and Culture. Tenth Edition. New York: McGraw-Hill Education.

Briggs, Asa \& Peter Burke. (2006). Sejarah Sosial Media "Dari Gutenberg sampai Internet". Jakarta: Yayasan Obor Indonesia.

Creswell, J.W. (1998). Qualitative Inquiry and Research Design: Choosing amongFive Tradition. London: Sage Publications.

Danesi, Marcel. (2010). Semiotika Media (terjemahan). Yogyakarta: Jalasutra.

Escarpit, Robert. (1966). The Book Revolution. London. George Harrap, Unesco.

Fidler, Roger. (2003). Metamorfosis: Memahami Media Baru. Yogyakarta: Bentang Budaya.

Fiske, John. (1990). Cultural and Communication Studies: Sebuah Pengantar Paling Komprehensif. Yogyakarta: Jalasutra

Hall, Stuart. (1997). Representation: Cultural Representations dan Signifying Practices. London: Sage Publications.

(2005). Representation: Cultural Representation and Signifying Practices. Ed. Stuart

Hall, Sage Publication: London.

Ibrahim, Idi Subandy dan Bachrudin Ali Akhmad. (2014). Komunikasi dan Komodifikasi: 
Mengkaji Media dan Budaya dalam Dinamika Globalisasi. Jakarta: Yayasan Pustaka Obor Indonesia.

Ignas Kleden, "Buku di Indonesia: Perspektif Ekonomi Tentang Kebudayaan", dalam Buku dalam Indonesia Baru, (Alfon Taryadi-ed.). Jakarta, 1999, hlm. 22.

Rakhmat, Jalaluddin. (1984). Metode Penelitian Komunikasi. Bandung: Penerbit Remaja Rosdakarya.

Gie, The Liang. (1992). Pengantar Dunia Karang Mengarang. Yogyakarta: Liberty.

Littlejohn, Stephen W \& Karen A. Foss. (2009). Teori Komunikasi, Edisi 9. Jakarta: Salemba Humanika.

McLuhan, Marshall. (1964). Understanding Media: The Extensions of Man, New York: McGrawHill.

Mc Quail, Denis. (2011). Teori Komunikasi Massa (Buku 6 Edisi 2). Salemba Humanika: Jakarta. Taryadi, Alfons (ed.). (1999). Buku dalam Indonesia Baru. Jakarta: Yayasan Obor Indonesia. Thompson, John B. (2004). Kritik Ideologi Global Teori Sosial Kritis tentang Relasi Ideologi dan Komunikasi Massa. Yogyakarta: Ircisod.

Thompson, John B. (1984). Studies in the Theory of Ideology. Berkeley: The University of California Press.

Scheder, Georg. (1976). Perihal Cetak Mencetak. Yogyakarta: Pusat Grafika Indonesia.

Sobur, Alex. (2004). Analisis Teks Media. Bandung: Remaja Rosdakarya. . (2004). Semiotika Komunikasi. Bandung: Remaja Rosdakarya.

Rusadi, Udi. (2015). Kajian Media Isu Ideologis dalam Perspektif, Teori, dan Metode. Jakarta: Rajawali Pers. 